Article

\title{
Drivers, Barriers and Benefits of the EU Ecolabel in European Companies' Perception
}

\author{
Fabio Iraldo ${ }^{1,2, *,+}$ and Michele Barberio ${ }^{1,2, *,+}$ \\ 1 IEFE-Institute for Environment and Energy Economics, Bocconi University, 20136 Milan, Italy; \\ fabio.iraldo@unibocconi.it or fabio.iraldo@sssup.it \\ 2 Sant'Anna School of Advanced Studies-Institute of Management, 56127 Pisa, Italy \\ * Correspondence: fabio.iraldo@unibocconi.it (F.I.); michele.barberio@unibocconi.it (M.B.); \\ Tel.: +39-347-040-076 (M.B.) \\ + These authors contributed equally to this work.
}

Academic Editor: Marc A. Rosen

Received: 25 December 2016 ; Accepted: 27 April 2017; Published: 4 May 2017

\begin{abstract}
To date, only a few studies have investigated the attitude of companies towards the EU Ecolabel. This article intends to provide an updated portrait of what are the main motivations that push companies to use the EU Ecolabel, the benefits that companies perceive as deriving from it and the barriers that companies perceive as hindering uptake. In order to answer to these research questions, we have used the data collected by the empirical survey on the EU Ecolabel that ran from April to July 2014. Evidence emerging from the survey shows that companies deem that the EU Ecolabel added-value lies in it being a useful "showcase" tool of their eco-innovation efforts, potentially able to close the information gap with the market (made of consumers above all, but also retailers and public procurers) about their products and services' environmental performance. However, there is evidence throughout the study that, although the EU Ecolabel brings some market rewards, these are fewer than those expected by companies when they first decide to apply for the EU Ecolabel. This is linked to the lack of awareness of the EU Ecolabel by consumers and to the insufficient and inadequate promotion and support granted by public institutions.
\end{abstract}

Keywords: EU Ecolabel; Ecolabels; ecoinnovation; drivers; barriers; benefits; survey; European businesses

\section{Introduction}

The objective of the EU Ecolabel Regulation (EC) 66/2010 is to establish a functioning, highly regarded Europe-wide voluntary ISO Type I Ecolabel [1], based on product and service requirements (so-called "criteria") that are appropriate for such an Ecolabel, aiming to encompass the top 10-20 percent of the market. Such criteria must be based on the latest scientific and technological considerations, be market-orientated, consider the most significant impacts and be simple to understand for consumers. The intention is that the EU Ecolabelling scheme will provide consumers with accurate, non-deceptive, science-based information on the environmental impacts of products and services, and will influence their purchasing decisions. Since its first release in 1992, a steadily growing number of companies have been awarded the EU Ecolabel. Indeed, EU Ecolabelled products numbers have increased steadily up to 44.711 as late as September 2015. However, the number of companies (licenses) stand at 2.031 in September 2015, which is modest for the whole of the European Union. Indeed, whilst generally increasing, the level of uptake for particular product groups is often very low and, for some others (such as a number of IT products), it is equal to zero. Figures 1 and 2 show the number of EU Ecolabel licenses and products/services in the period 2011-2015 (official data of the European Commission). 


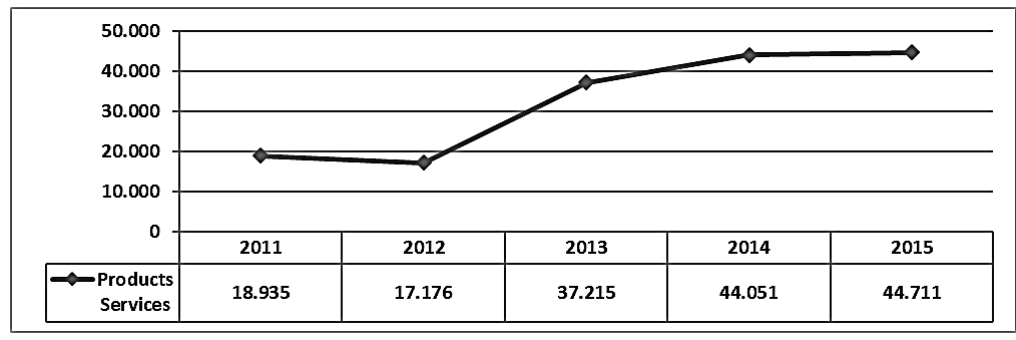

Figure 1. Numbers of EU Ecolabel products and services.

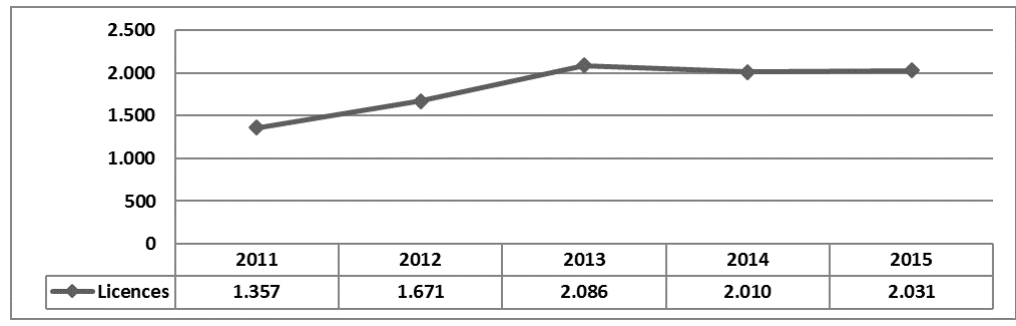

Figure 2. Numbers of EU Ecolabel Licences.

These data suggest the persistence of a series of barriers against a much higher uptake of the EU Ecolabel and the perception among companies that the benefits deriving from the EU Ecolabel are insufficient and not always in line with the drivers that have pushed them to apply for the EU Ecolabel.

\section{EU Ecolabel Drivers, Benefits and Barriers: A Literature Review}

There is a large amount of literature available on Ecolabelling and product labelling that has investigated and analysed the role of Ecolabels in companies' market and eco-innovation strategies (please see Appendix A to the main text). As for the EU Ecolabel itself, however, much of the available contributions come from the 2006 EU Ecolabel Evaluation Study, the EVER study (2006 Evaluation of the EU Ecolabel carried out on behalf of Directorate General for the Environment of the European Commission by a consortium of consultants. The Consortium was led by IEFE Universitä Bocconi and was also composed by Adelphi Consult, IOEW, Office Heidelberg, SPRU, Sussex University and Valør and Tinge A/S.) and from the evaluation studies of other prominent ISO Type I Ecolabels, mainly the Nordic Ecolabelling scheme. Before our study, the EVER study, in particular, was the only existing comprehensive assessment specifically dedicated to the EU Ecolabel. Therefore, it has represented a primary reference for our investigation.

\subsection{Drivers}

Ecolabelling schemes, whose primary function is that of being communication tools, aim to close the information gap between operators providing environmentally friendly products/services and consumers making purchasing choices on the market. Therefore, Ecolabels have a specific role in contributing to the overall awareness of the environmental impacts of products and services. The EVER study (2006) found that companies apply for the EU Ecolabel to take advantage of business opportunities offered by consumers' increased awareness of environmental issues, and to satisfy customers' specific requests for products and services with high environmental quality. Indeed, in a quantitative analysis carried out by Testa et al. [2] to assess whether the EU Ecolabel can stimulate eco-friendly behavior, the authors show that Ecolabels in general play a significant role of "guarantee" for consumers and, consequently, are able to guide consumers' choices toward products and services with a higher environmental quality. Considering these initial considerations, it can be argued that one of the most powerful drivers for companies to choose the EU Ecolabel is the need to respond to external pressures coming from the "demand side", i.e., final consumers and 
intermediate customers, who ask for reliable and clear information on the products and services that are presented as "green". This argument is in line with most of the existing studies, which basically agree with the assumption that societal pressures and market requirements affect the decision of companies to invest in eco-innovation [3-5]. Ecolabels, in particular, aim at establishing a reliable and trustworthy information system on products' environmental qualities [6] and are used by companies as a marketing and communication tool targeting customers and consumers in order to increase market share. Triguero et al. [7] hold that companies introduce eco-innovative products and services into the market only when it is rewarding. Even considering that environmental product innovations might be costlier than non-environmental ones, companies may decide to accept lower short run profits in order to reach higher mid-term and long-term business goals. In fact, Gulbrandsen [8] refers to Ecolabels as market-based instruments aimed at internalizing environmental externalities through prices. In other words, the decision to use Ecolabels by the business sector is driven by the aspiration to extract a premium price on Ecolabelled products/services and to gain greater access to markets, including the opportunities offered by green public procurement policies.

\subsection{Benefits}

As seen, companies elect to use Ecolabels driven by the fact that they see an opportunity to add value to existing products, expand their reach in existing markets, or maintain market share in a competitive environment. Literature does not provide much quantitative or qualitative research on the economic and environmental benefits really achieved by companies that are awarded an Ecolabel. This is due mainly to the lack of agreed research parameters and the breadth of interrelated implications that Ecolabels have for the different stakeholders. Consequently, so far, assessments on the benefits of Ecolabels have been provided mainly by the evaluation studies carried out for both the EU Ecolabel and one of its main (national) "competitors", the Nordic Ecolabelling scheme. The portrait delivered by the EVER study (2006) empirical research, for instance, illustrates that the direct benefits actually achieved by companies are related to the improvement of the environmental impact of their activities and, secondly, to their economic or competitive performance. Companies indicated a better environmental performance as the main advantage brought by the EU Ecolabel, along with the recognition as a leader by competitors or other relevant actors. Looking in detail at the environmental effects of the use of the EU Ecolabel, almost half of interviewees indicated that the EU Ecolabel had some effect on the environmental performance of the product in the areas of air and water emissions, waste/recycling and water/material use. Furthermore, it is interesting to report that approximately 42 percent of the EU Ecolabel Licence holders declared that the EU Ecolabel helped them in setting targets for environmental improvements of their products/services for all or most areas, and this was thanks to a better and deeper knowledge of the environmental impact of their products/services. As for the capability of the EU Ecolabel to enhance competitiveness and profits, the results of the EVER study (2006) showed that it can positively, even if "softly", contribute to the increase of market shares and sales. In fact, the EU Ecolabel was considered able to produce positive effects on the market, as 53 percent of the interviewed companies experienced an increase in the market share or in the number of new customers thanks to holding products awarded with the EU Ecolabel. However, market reward in terms of turnover was deemed to not be easily measurable, given that only 29 percent of respondents could quantify the impact of the EU Ecolabel on turnover. Kjeldsen et al. [9], performing the evaluation of the Nordic Ecolabel, report that several of the interviewed companies explained that they were first movers on the market and gained a competitive advantage for this in the first few. Moreover, the same study found that companies managed to increase consumer/customer interest because the Ecolabel had improved their environmental profile and helped them communicate this to the market. Some companies indicated that being awarded with the Nordic Ecolabel led to increased sales and new customers, while other highlighted that they were able to target new segments of customers that they would not have reached without the label. Interestingly, other interviewed companies reported that the Nordic Ecolabel had not brought an increase in sales as they expected, but they also thought 
that without the label they would have lost market share. Lastly, companies awarded with the Nordic Ecolabel declared significant gains in terms of resource efficiency (energy, water, waste). This emerged as being particularly true for companies who had held an Ecolabel for their entire service or production facility, such as hotels, or having several products awarded with the Ecolabel. Thidell [10] reports how the Nordic Ecolabel has helped Licence holders to increase their market share and improve their environmental performance, especially for companies operating in those product groups (such as household detergents and copy paper) that seemed to be "suited" for the Ecolabel and that, therefore, have showed a reasonable amount of Ecolabel products sold.

\subsection{Barriers}

Our analysis has confirmed competitive factors and market pressure as the main drivers for applying for Ecolabels, and the EU Ecolabel specifically. Despite the proliferation of Ecolabels and their diffusion on the market because of businesses' willingness to meet customer/consumer expectations, companies, especially SMEs, are still facing difficulties when applying for Ecolabels.

The EVER study (2006) found that the main obstacles that Licence holders faced with the EU Ecolabel were associated with aspects such as "red tape/documentation" and "costs of complying with criteria". Interestingly, factors such as "lack of human resources and skills" as well as "application procedures slow and very bureaucratic" were not indicated as major barriers by companies. When Non-Licence holders were asked about the barriers and obstacles that made them decide either to abandon or not to apply for the EU Ecolabel, they revealed that the main barriers were related to: lack of recognition and rewards by public institutions (green procurement), customers, consumers, and retailers; high costs of implementation (including consultants); high cost of the license; and lack of economic incentives (including funding). Indeed, as for the cost of certification, Lozano et al. [11] argued that the survival of an Ecolabel in the long run may also depend, among other variables, on how expensive it is for a company to obtain and maintain the licence. Kjeldsen et al. [9], reporting the results of a survey on the Nordic Ecolabel, found that the main barriers faced by a company when applying for the Nordic Ecolabel are mainly related to the overall cost of implementation and to the application procedure. As for the first one, interviewed companies argued that, besides direct costs for obtaining the label, a number of indirect costs arise when implementing the Nordic Ecolabel. Interestingly, companies considered these costs as being even higher than direct costs. Although companies declared that these costs are difficult to quantify and that they did not have a complete overview of them, they were nevertheless able to indicate them as related to the application procedure, and the needs to make changes to the production process, hire consultants (including testing activities), and train employees. As for the second barrier mentioned by companies and related to the application procedure, they found it difficult and time-consuming to collect the necessary documentation. In particular, companies willing to license a product/service declared that most of the time used has to be dedicated to understanding the criteria and collecting documentation. Furthermore, they specified that in collecting documentation they had to engage in a closer communication and dialogue with suppliers and subcontractors. However, a study by Martins Geneix [12] still reported that companies, particularly SMEs, consider that the main weaknesses of the EU Ecolabel are the cost of obtaining the EU Ecolabel, especially the costs related to testing, the lack or promotional activities by competent authorities (including incentives) and the time (too long) needed to revise the criteria.

\section{EU Ecolabel Drivers, Benefits and Barriers: Evidence from the EU Ecolabel Evaluation Survey}

As seen in the previous section, the existing literature provides limited updated analysis on companies' attitude towards the EU Ecolabel, with few distinctions between SMEs and Larger companies and/or without taking into account those companies that have not decided to apply for the EU Ecolabel. This section intends to close this research gap and deliver an empirically informed representation of: 
- what are companies' drivers for the EU Ecolabel. Factors that bring companies to use the EU Ecolabel in order to take advantage of expected potential paybacks;

- what are companies' benefits of the EU Ecolabel. Direct paybacks that companies obtained as a result of having their products or services awarded with the EU Ecolabel and if they are in line with the motivations that pushed them to start the process of implementation;

- what are companies' perceived barrier for the EU Ecolabel. Administrative, procedural and economic factors that prevent a greater uptake by companies.

These research questions have been investigated by means of a EU-wide survey developed for stakeholders' consultation within the 2014/2015 EU Ecolabel Evaluation study ("Study to Support the Evaluation and Implementation of the EU Ecolabel Regulation") carried out for the European Commission by Ricardo-AEA and IEFE-Bocconi University. The survey, developed in close consultation with the DG Environment, explored these aspects through the experiences of the EU Ecolabel Licence holders, both SMEs and Larger companies, who are obviously directly involved with the EU Ecolabelling scheme and can provide useful considerations and insights drawn from their experience. However, when possible and to a more limited extent, it also sought input from Non-Licence holders, companies that had been awarded the EU Ecolabel but that decided to give it up or companies that have considered applying for the EU Ecolabel but have renounced it because of barriers for uptake. This latter category was expected to provide useful information and insights into the drivers that could trigger a Non-Licence holder's decision to apply for the EU Ecolabel, as well as the barriers that they perceive. Nevertheless, it must be acknowledged that a much more limited number of Non Licence holders have responded to the survey if compared to the number of companies bearing the EU Ecolabel. As for the survey questions, these were posed either as yes/no questions (questions on the drivers and benefits) or asked whether the respondent agreed or disagreed with a range of statements (question on the barriers; range: strongly agree, agree, neutral, disagree, strongly disagree). Within the analysis performed throughout the work, "strongly disagree" corresponds to a numerical score of 1 , while "strongly agree" corresponds to a numerical score of 5 . Furthermore, throughout the questionnaire, respondents were given the opportunity to provide detailed text comments about the aspects of the EU Ecolabel under consideration, and these have been drawn upon to inform the insights identified. However, interviews via telephone or face to face were carried out in order to get further insights and understanding of survey responses. In order to publicize the survey as much as possible, and draw the widest audience into it, the survey was publicized through the project website, through blogs and announcements on the project team's websites, and through trade press announcements. A link from the front page of the Commission's EU Ecolabel page to it was also provided. A total of 126 companies fully completed the online questionnaire:

- $\quad 106$ EU Ecolabel Licence holders (of a wide range of product groups), of which 59 were SMEs;

- 20 Non Licence holders, of which eight were SMEs.

Figures 3 and 4 below provide information about the country of origin of the respondents and the EU Ecolabel product category/economic sector. 


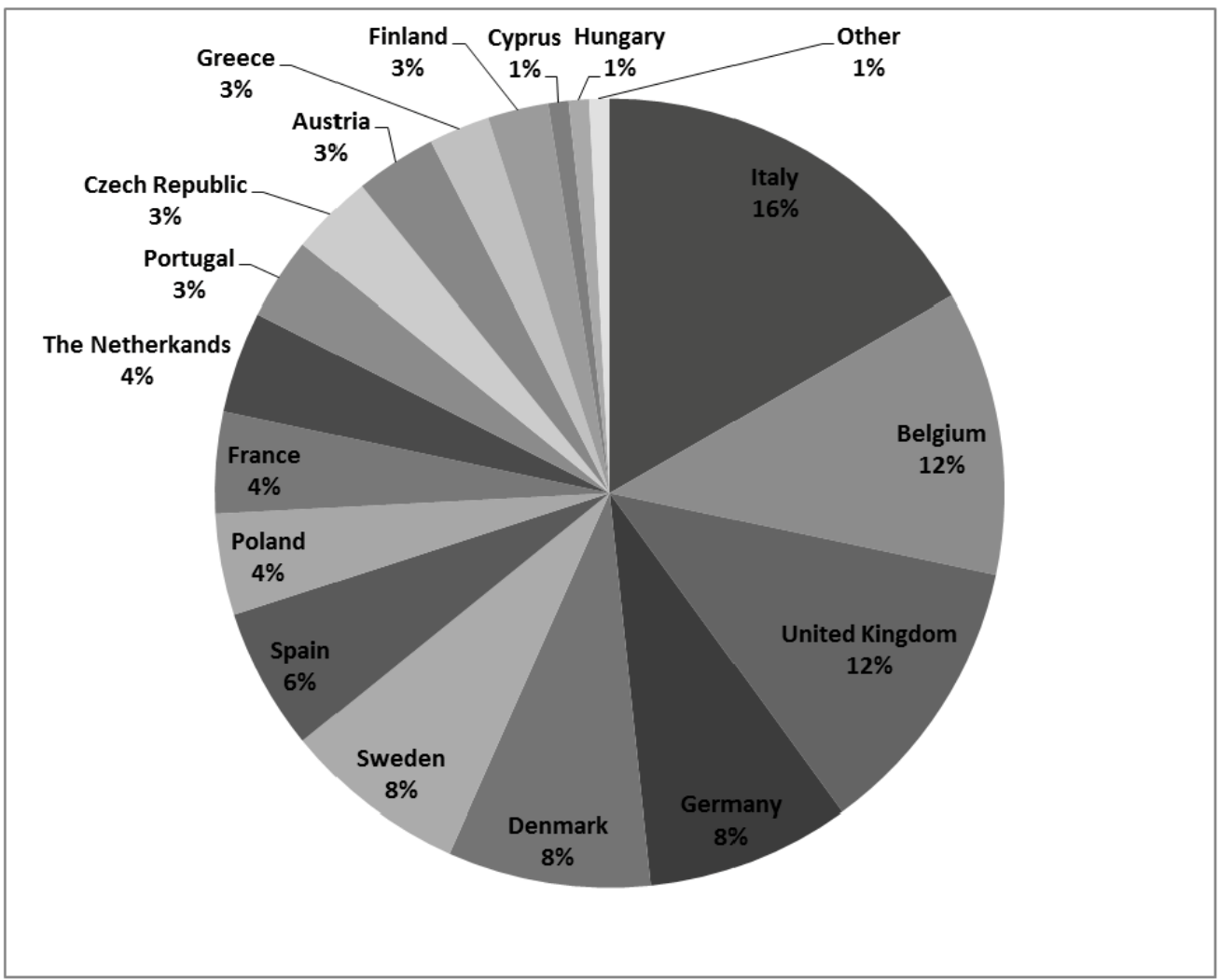

Figure 3. EU country of origin of the EU Ecolabel survey respondents.

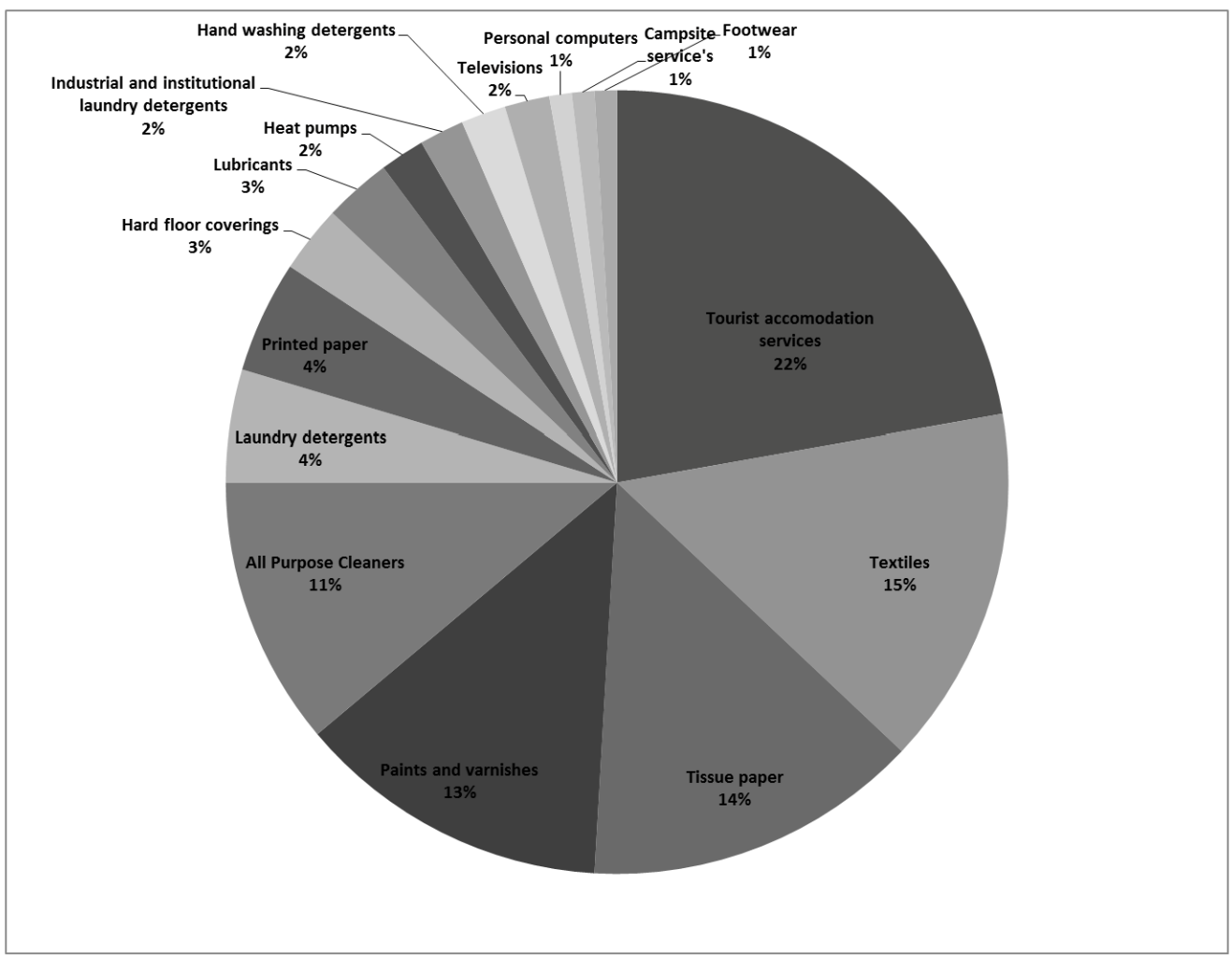

Figure 4. EU Ecolabel product/service group category of the survey respondents. 


\subsection{Drivers}

The results of our study are in line with the findings in existing literature and, particularly, with the 2006 EVER study. More precisely, results show that around 60 percent of the Licence holders adopt the EU Ecolabel as a tool to respond to market pressure deriving from both important customers (including retailers) and consumers, and thus increase sales and improve their overall market competitiveness (Figure 5). A very similar picture emerges from the analysis of the responses of the surveyed non-license holding companies, although some differences may be highlighted. Indeed, results reveal a slightly different pattern with respect to companies that have adopted the EU Ecolabel. Once again, market factors are demonstrated as being the main drivers that may push them to apply for the EU Ecolabel, improve the competitiveness or market positioning of the product and improve their capabilities to respond to customers/consumers request are at the top of the drivers list. However, two further issues fall into the group of critical motivations for applying for the EU Ecolabel: the willingness to better manage specific environmental issues within the company and to increase customer/consumer interest and satisfaction.

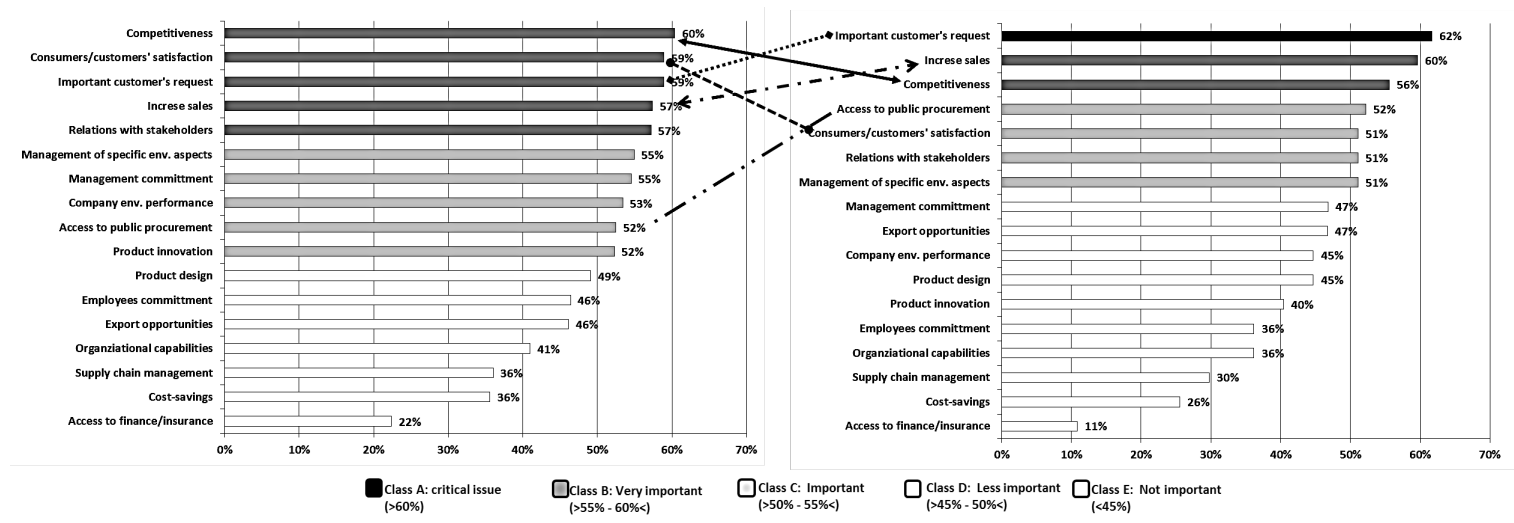

*Number of Licence holders that have responded: 106

${ }^{*}$ Number of Non-Licence holders that have responded: 20

Figure 5. Licence holder (right) and Non-license holder (left) responses to the consideration of drivers to use the EU Ecolabel.

These results suggest that companies are operating in a framework of increased competitiveness, where the capability to respond to an increased pressure arising from growingly environmentally aware final consumers, intermediate customers and retailers is seen as a strategic lever when aiming at improving market positioning. It is important to note that some companies specified also that, when important customers pushed them to apply for the EU Ecolabel, these were often big retailers. As retailers are the interface between the upstream supply chain and the final consumer, a sort of "gatekeeper", they are held accountable by consumers and stakeholders for product issues such as chemicals of concern, excessive packaging and sourcing responsibly produced materials and products. Consequently, retailers emerge as important actors in driving companies' environmental policies (and consumers' purchasing choices). Besides the differences between License lolders and Non-License holders in the order in which the two groups of respondents rated their answers (emphasized in Figure 5), the statistical significance of these differences was analyzed by performing the Mann-Whitney $U$ test. It is a nonparametric test, which does not require normal distributions, and which tests the dependence of two samples that come from the same population by comparing their mean [13]. As it can be seen from Table 1, the test confirms that the two groups of respondents attribute the same importance to the investigated drivers, with the only exception of the "supply chain management". 
Table 1. Drivers-License holders and Non-License holders-Mann-Whitney U test.

\begin{tabular}{lccc}
\hline \multirow{2}{*}{ Drivers } & \multicolumn{2}{c}{ Weighted Mean } & \multirow{2}{*}{ Mann-Whitney U Test } \\
\cline { 2 - 3 } & Licence Holders & Non-Licence Holders & - \\
\hline Important Customer's request & 0.88 & 0.92 & - \\
Increase sales & 0.81 & 0.72 & - \\
Cost savings & 0.33 & 0.26 & - \\
Access to public procurement & 0.68 & 0.71 & - \\
Export opportunities & 0.65 & 0.60 & - \\
Consumers/customers' satisfaction & 0.88 & 0.90 & - \\
Relations with stakeholders & 0.75 & 0.88 & - \\
Employee commitment & 0.61 & 0.81 & - \\
Management commitment & 0.69 & 0.73 & - \\
Management of specific environmental aspects & 0.76 & 0.71 & - \\
Company environmental Performance & 0.80 & 0.71 & $*$ \\
Organizational capabilities & 0.58 & 0.61 & - \\
Supply chain management & 0.50 & 0.21 & - \\
Product innovation & 0.66 & 0.64 & - \\
Product design & 0.62 & 0.50 & - \\
Access to finance/insurance & 0.21 & 0.20 & - \\
\hline
\end{tabular}

$*, * *$, and ${ }^{* * *}$ indicate the significance at the 10 percent, 5 percent, and 1 percent levels, respectively.

If we analyze the results taking into account companies' size (Figure 6), the picture that emerges is very similar to that given overall. SME and Larger Licence holders consider market factors as significant drivers for applying for the EU Ecolabel. However, it must be noted that SMEs identified the ability to respond to a specific request made by an important customer or retailer as only the third driver in order of importance. In contrast, larger companies see this driver as the major motivation for applying for the EU Ecolabel, followed by the desire to increase sales, improve products' competitiveness on the market and access public procurement opportunities.

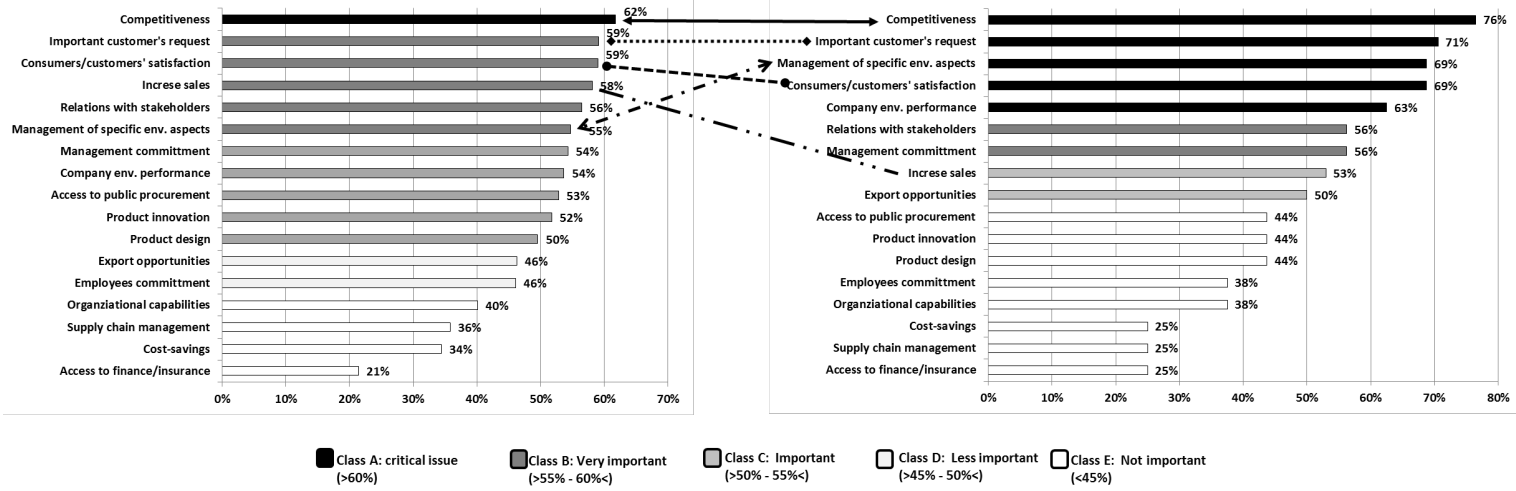

Number of SME Licence holders that have responded: 59

Number of larger Licence holders that have responded: 47

Figure 6. SME (right) and Larger License holder (left) responses to the consideration of drivers to adopt the EU Ecolabel.

\subsection{Benefits}

The evidence emerging from our study shows (Figure 7) that market gains are at the top of the benefits delivered, at least for those companies that have experience with the EU Ecolabel (i.e., Licence holders). In line with the results emerging from our literature review, companies stated that the improvement of competitiveness and the increase of customers/consumer's interest and satisfaction are the major gains derived from obtaining the EU Ecolabel. These results are even more telling if we consider that they emerge despite a widespread perception among surveyed Licence holders of a general low awareness and visibility of the EU Ecolabel on the market. This may 
be an explanation for the benefit "increased sales" not ranking at the top of the gains obtained, although placing quite high. This may suggest that, despite the improvement of brand image, consumers' trust and access to larger markets, the paybacks in terms of sales are deemed lower than expected ("increased sales" is ranked higher as a driver than as a real benefit). It must also be noted that when asked about data on sales of EU Ecolabel products as demonstration of the scheme's effects on competitiveness, Licence holders were not able or did not want to provide such information because of a declared "commercial sensitivity" of this kind of information. Alongside market factors, the improvement of the overall environmental performance of the company is also indicated as a benefit resulting from being awarded the EU Ecolabel. Interestingly, this option was not ranked so highly as a driver, so this can be considered as a benefit that many companies would not necessarily be expecting at the outset of the process, the limited impact possibly depending on the ratio between the number of EU Ecolabel products and the overall production. More in general, these findings on the "ex-post" perceived benefits reinforce the picture emerging from the "ex-ante" analysis of the drivers to the Scheme: companies apply for the EU Ecolabel because they consider it a market- and consumer-oriented tool. The improvement of the company's environmental performance is a "secondary" driver, especially when the application for the EU Ecolabel is perceived as an ultimate guarantee to consumers of a much broader sustainability strategy. The results of the Mann-Whitney U test applied to the differences between Licence holders and Non-Licence holders (reported in Table 2 here below) show that there is no significant divergence between the perception of these two groups of respondents, for none of the benefits that have been investigated in the questionnaire.

Table 2. Benefits-License holders and Non-License holders-Mann-Whitney U test.

\begin{tabular}{lccc}
\hline \multirow{2}{*}{ Benefits } & \multicolumn{2}{c}{ Weighted Mean } & Mann-Whitney U Test \\
\cline { 2 - 3 } & Licence Holders & Non-Licence Holders & - \\
\hline Important Customer's request & 0.82 & 0.76 & - \\
Increase sales & 0.37 & 0.26 & - \\
Cost savings & 0.33 & 0.26 & - \\
Access to public procurement & 0.72 & 0.71 & - \\
Export opportunities & 0.69 & 0.60 & - \\
Consumers/customers' satisfaction & 0.90 & 0.92 & - \\
Relations with stakeholders & 0.78 & 0.92 & - \\
Employee commitment & 0.67 & 0.74 & - \\
Management commitment & 0.70 & 0.73 & - \\
Management of specific environmental aspects & 0.75 & 0.76 & - \\
Company environmental Performance & 0.83 & 0.73 & - \\
Organizational capabilities & 0.65 & 0.35 & - \\
Supply chain management & 0.46 & 0.61 & - \\
Product innovation & 0.69 & 0.50 & - \\
Product design & 0.65 & 0.07 & - \\
Access to finance/insurance & 0.20 &
\end{tabular}

If we look at the findings regarding the sub-group of licence holding SMEs, results again do not change much as they identify two main areas of payback, namely, enhanced competitiveness of products/services, and improved customers/consumers' satisfaction. Thirdly, respondent SMEs indicate that the improvement of the environmental performance of the company as a benefit delivered through participation in the scheme. As for larger companies, they identify the increased consumer/customer interest and satisfaction as a major benefit of the EU Ecolabel, followed by the improvement of the overall environmental performance of the company. Larger companies also ranked more highly as a payback the improvement of competitiveness on the market. The comparison of these results with the EVER study shows a change in companies' perception of the benefits of the EU Ecolabel. Back in 2006, companies stated that the main benefit brought by the EU Ecolabel was the overall improvement of their environmental performance, while the improvement of the competitive performance (new customers and increased market share) came only secondly. Today, companies see the EU Ecolabel less as a way for reducing their impact on the environment and 
more as a market instrument to take advantage of the opportunities offered by a greening retailing and public procurement environment. This may be linked to the consideration that one of the main objectives of the 2009 revision of the EU Ecolabel Regulation was to reinforce the EU Ecolabel as a label of environmental excellence, increasing uptake by companies whose products and service already have the lowest impacts on the environment. This aspect has been rightly affirmed as central to the revised EU Ecolabel Regulation, where Articles 6.3 and Annex I call for the criteria development and revision process to be centred on life-cycle approach and key environmental aspects. Furthermore, the surveyed companies have stressed that the effectiveness of the EU Ecolabel in terms of improving environmental performance is generally difficult to measure, owing mainly to (1) the very specific nature of the EU Ecolabel and, more precisely, the fact it is a multi-criteria ISO Type I environmental label addressing a wide range of environmental aspects; and (2) difficulties in isolating the environmental benefits achieved due to the EU Ecolabel from the environmental benefits attained by the implementation of other isolated environmental measures, such as energy efficiency measures, chemical substances, environmental management systems, and supply chain management, etc. However, EU Ecolabel service providers (namely hotels) have shown a higher capability of measuring their environmental improvement given that the whole accommodation facility must be addressed when adopting the scheme.

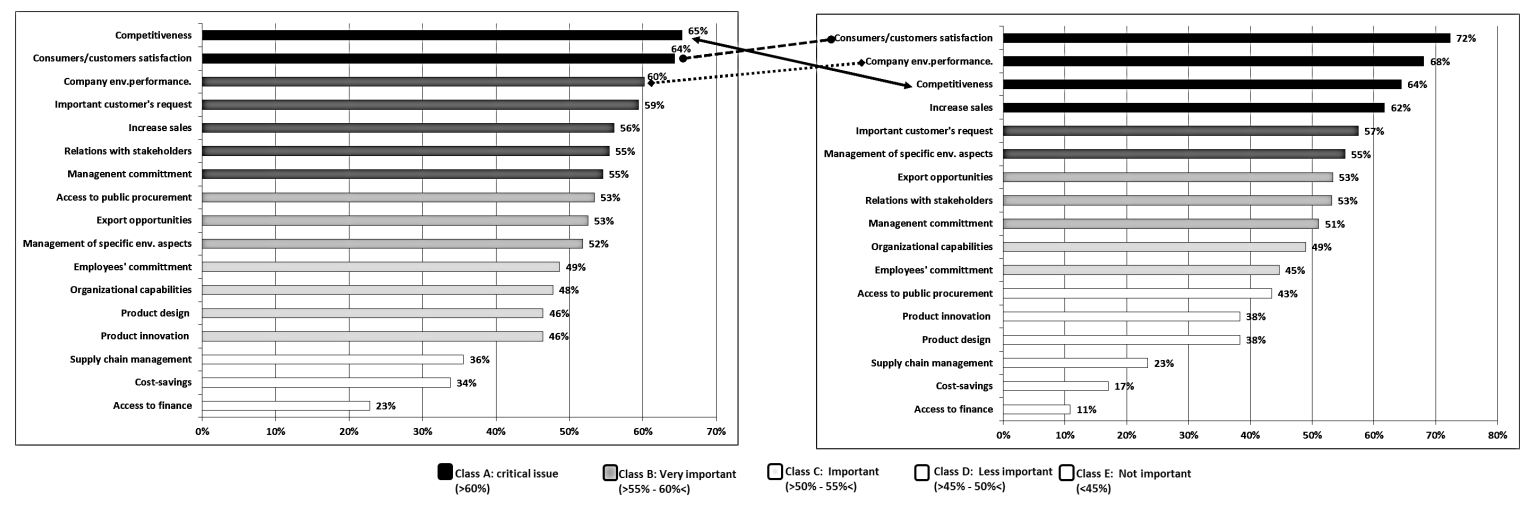

Number of SME Licence holders that have responded: 59

Number of larger Licence holders that have responded: 47

Figure 7. SME (right) and Larger (left) License holder responses to the consideration of the benefits gained.

\subsection{Barriers}

Our study also provided a picture of the problems and difficulties that companies encounter, or may encounter, when applying and holding an EU Ecolabel licence and that could prevent them fromapplying. Results demonstrate that a series of important barriers still exist (Figure 8). In Licence holders' view, these are the following: too much documentation/red tape required, lack of external incentives (including fiscal incentives and access to public procurement) and lack of competitive rewards and advantages. Please note that, for this question, it has been asked whether the respondent agreed or disagreed with a range of statements (values from 0 to 5). 


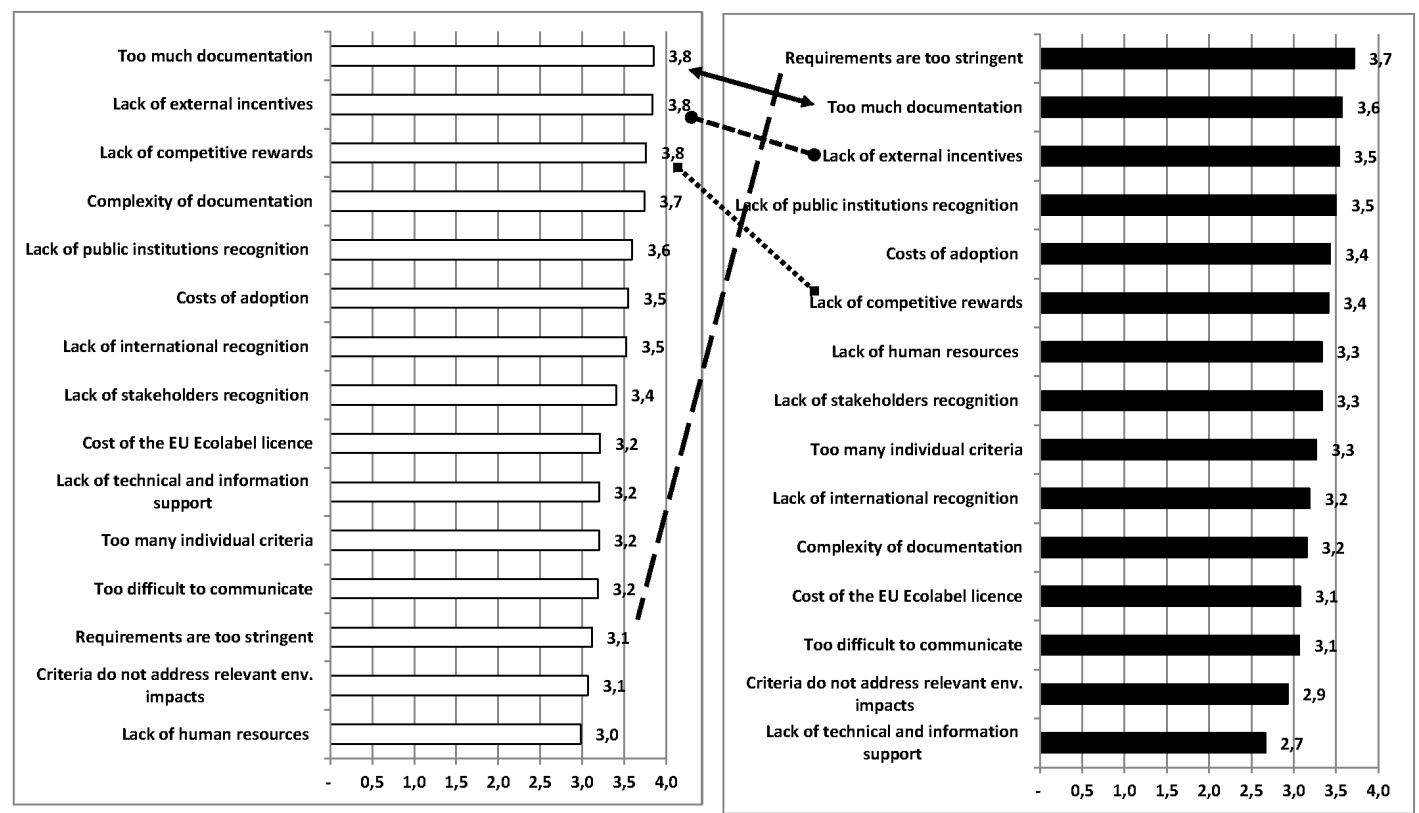

${ }^{*}$ Number of Licence holders that have responded: 106

*Number of Non-Licence holders that have responded: 20

Figure 8. Licence holder (right) and Non-License holder (left) responses to the consideration of barriers to use the EU Ecolabel.

License holders believe that the required documentation is too much and complicated and this is highlighted as a major difficulty. As emerging from a significant number of interviews that have complemented the survey, this translates into a very time-and resource-consuming process of obtaining an EU Ecolabel licence. If compared to the results of previous evaluation study (EVER, 2006), these results seem to be coherent with License holders' answers back in 2006 where documentation (too much, too complex, and not always easy to collect when dealing with suppliers) and cost of implementation were reported as major barriers. Companies still perceive bureaucracy as a major problem and ask for streamlined assessment and verification procedures. As for the "lack of external incentives", this can be paired with the "lack of recognition by public institutions". Companies show a rather high agreement on the lack of institutional support and recognition as the survey and interviews reveal that they believe public institutions should incentivize and support the EU Ecolabel by means of fiscal and regulatory relief measures, i.e., easier access to public procurement, tax reduction, simplifications of permitting procedures, etc. As for the "lack of competitive rewards and advantages", this emerges as closely linked to the lack of tailor-made external incentives for rewarding companies that propose more environmentally friendly products to the market. It is interesting to note that, while companies indicated improved competitiveness and better market positioning as the main benefits deriving from holding an EU Ecolabel license, at the same time, they declare that they experienced an insufficient market response. This may suggest that, even if the EU Ecolabel brings some market benefits, they are lower than those expected by companies applying for the EU Ecolabel. The surveyed companies perceive this barrier as mainly linked to the lack of awareness of the EU Ecolabel by consumers and to the insufficient and inadequate promotion of the Scheme by public institutions and the EU. As it emerged from some interviews, though, this perception may also be linked to the fact that Licence holders do not systematically collect data on sales of EU Ecolabel products. A general outcome of the interviews we carried out in our study is that there is a generalised 
lack of information on the effective market performance of EU Ecolabel products. As for the cost of adoption, it is not perceived as a prominent barrier. Surprisingly, the survey results show that companies do not suggest (or ask) to reduce the administrative costs for participants (e.g., reducing the costs of license and new fee structures) as a way to lower the barriers for the EU Ecolabel. However, it should be noted that the cost of complying with criteria (e.g., cost of testing activities) ranks high in survey results, so this is still perceived as a barrier to the EU Ecolabel by companies. It is worth stressing again that, as seen in previous points, companies deem that the lack of high market returns and incentives by public institutions (fiscal incentives and easier access to public procurement) are far more important barriers than costs. Companies see the issue more in terms of a reduction of the market costs through supporting funding, i.e., through fiscal incentives such as tax abatements in order to reduce market prices with benefits for final consumers. In summary, reducing market costs via financial incentives seems to be more promising than reducing the financial administrative costs. Criteria stringency and the lack of human resources are not perceived as major problems by EU Ecolabel Licence holders. Licence holders also do not consider the EU Ecolabel difficult to communicate to the market and to stakeholders. As for Non-Licence holders, although agreeing with Licence holders when considering the amount of documentation required and the EU Ecolabel's general lack of recognition and public incentives, they give far greater importance to the criteria requirements of the EU Ecolabel being too stringent and give this as a major barrier. For barriers, we have also applied the Mann-Whitney $U$ test, which, in this case, shows some relevant divergence in the perception of the two groups (Table 3). In particular, there is an opposite view on such issues as the complexitiy of the documentation required by the EU Ecolabel and the lack of support (which has been experienced much more by those companies that have obtained and maintained the EU Ecolabel), and for the stringency of the requirements that, on the opposite side, is perceived as a barrier more by Non-Licence holders. (Table 3).

Table 3. Barriers-License holders and Non-License holders-Mann-Whitney U test.

\begin{tabular}{lccc}
\hline \multirow{2}{*}{ Barriers } & \multicolumn{2}{c}{ Weighted Mean } & Mann-Whitney U Test \\
\cline { 2 - 3 } & Licence Holders & Non-Licence Holders & - \\
\hline Cost of the application & 3.54 & 3.35 & - \\
Cost of the EU Ecolabel licence & 3.20 & 3.05 & - \\
Too much documentation & 3.84 & 3.47 & - \\
Complexity of documentation & 3.74 & 3.11 & - \\
Requirements are too stringent & 3.11 & 3.58 & - \\
Lack of human resources & 2.98 & 3.31 & - \\
Lack of technical and information support & 3.17 & 2.70 & - \\
Lack of external incentives & 3.73 & 3.47 & - \\
Lack of competitive rewards & 3.69 & 3.29 & - \\
Lack of stakeholders recognition & 3.37 & 3.29 & - \\
Lack of public institutions recognition & 3.55 & 3.47 & - \\
Lack of international recognition & 3.50 & 3.17 & - \\
Too difficult to communicate & 3.18 & 3.05 & - \\
Too many individual criteria & 3.20 & 3.23 & - \\
Criteria do not address relevant env. impacts & 2.98 & 2.76 & - \\
\hline
\end{tabular}

If the responses are broken down by Licence holders size (Figure 9), differences do emerge. SMEs show a higher agreement with the concept that the EU Ecolabel lacks support in terms of both external incentives and recognition by public institutions. The amount and complexity of documentation together with the lack of recognition at the European and international level and of competitive rewards on the market are also seen as major barriers to apply for the EU Ecolabel. Larger companies see the main barriers as relating to the volume and complexity of the documentation required. Larger Licence holders also agree with the lack of incentives, including fiscal incentives, easier access to public procurement and the lack of competitive paybacks as being the major barriers. 
For larger Licence holders, the criteria requirements themselves and the potential lack of human resources are not major barriers when considering the adoption of the EU Ecolabel.

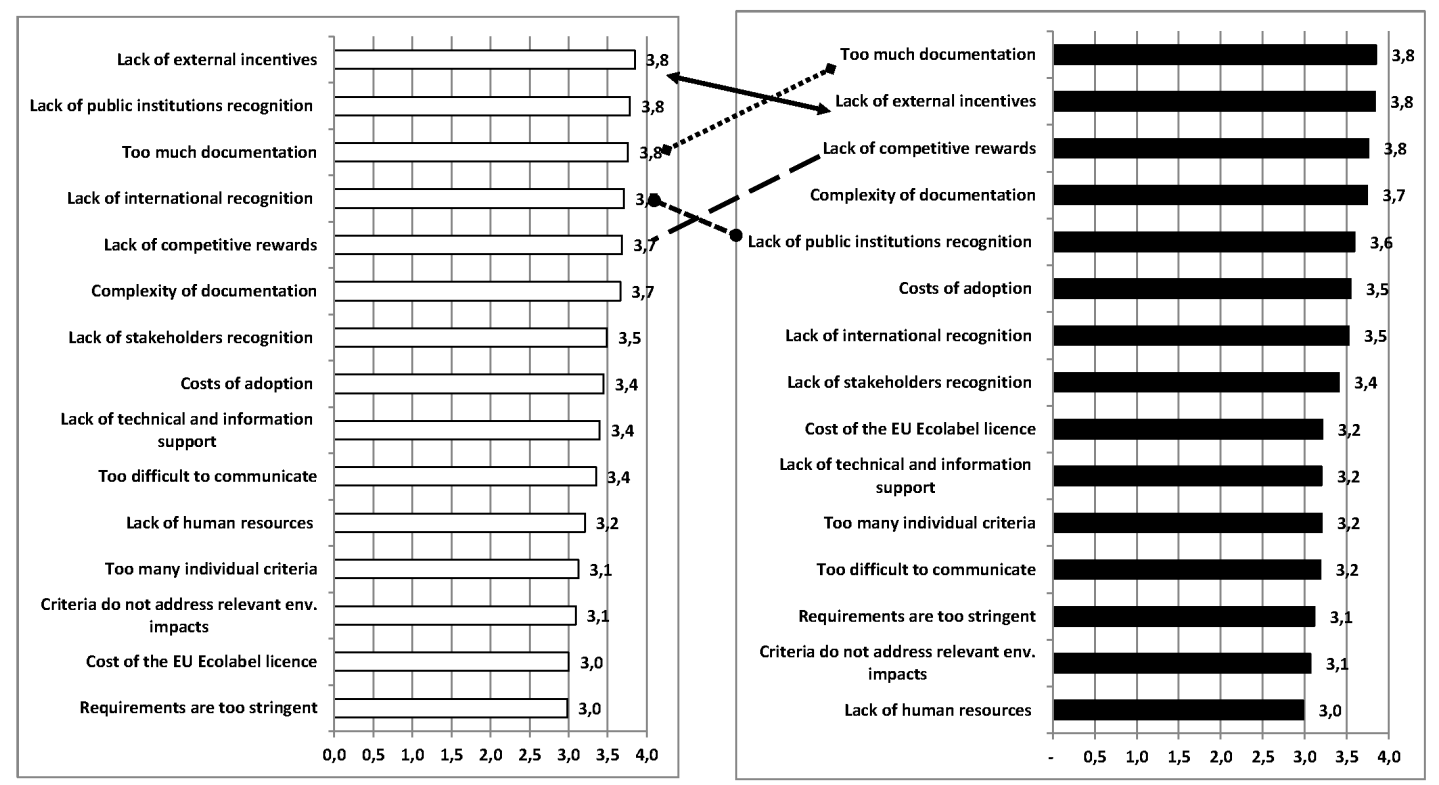

Number of SME Licence holders that have responded: 59

Number of larger Lincence holders that have responded: 47

Figure 9. SME (right) and Larger Licence holder (left) views of the barriers a company may face when considering adoption of the EU Ecolabel.

\section{Discussion}

The market is a key element in companies' perception of and experience with the EU Ecolabel. Market factors such as increased competitiveness and enhanced capabilities to respond to customers??/consumers' demands are seen by companies as motivations to apply for the EU Ecolabel, and they are also perceived as real benefits, once the EU Ecolabel is adopted and used as a marketing tool. Nevertheless, the (still limited) market response is also seen by companies as one of the main barriers that they have to tackle. In fact, the demand for Ecolabelled products is deemed as insufficient by companies. To confirm this, a considerable share of respondents to our survey identified that the EU Ecolabel's actual effects in terms of sales are not satisfactory. Thus, the results of our study undoubtedly show that the barriers to the uptake of the EU Ecolabel are still high and that the perceived drivers might be ineffective. The inadequate market response to EU Ecolabel products and services is essentially linked, in the companies' view, to the lack of awareness on the EU Ecolabel by consumers and to the insufficient promotion, inadequate recognition and incentivisation of the EU Ecolabel by public institutions (including national and EU authorities).

These two factors emerge repeatedly as the main barriers and shortcomings of the EU Ecolabel, and, prospectively, give important indications on what companies deem necessary for increasing the appeal of the EU Ecolabel: a much stronger and more effective communication and marketing approach to stimulate the market for Ecolabelled products and services. Paragraph 13 of the EU Ecolabel regulation highlights that it is necessary "to inform the public and to raise public awareness of the EU Ecolabel through promotion actions, information and education campaigns, at local, national and Community levels, in order to make consumers aware of the meaning of the EU Ecolabel and to enable them to make informed choices. It is also necessary in order to make the scheme more attractive to producers and retailers". Article 12 specifically addresses this objective by requiring an action plan to be developed for this activity. At the moment, a specific communication action plan between Member 
States and the Commission has not been developed yet; however, very few and scattered promotional activities have been implemented to support the requirements under Article 12 of the Regulation, at both Member State and EU levels.

Moreover, companies' perception and adoption of the EU Ecolabel can be directly correlated to how complex and cost-effective they consider the scheme to be. The feedback received during our survey highlighted that the Licence fee is not a cost barrier itself. Of greater consideration are the sometimes-significant costs involved in demonstrating compliance with the criteria requirements, and gaining the test results and verifications that are necessary to obtain the label. This emerges as a significant barrier for Licence holders, regardless of their size, as well as for Non-Licence holders and translates also into the consideration that the documentation required for obtaining and maintaining the EU Ecolabel is too much and too complicated. Finally, from the point of view of the License holders, costs are high because of the lack of promotion and support through external incentives, including fiscal ones. Thus, companies see the reduction of market costs via financial incentives as being preferable than reducing the financial administrative costs. The 2006 EVER study already suggested this, as one of the main areas of intervention in order to increase the effectiveness of the EU Ecolabel as a tool to support the creation of a Europe-wide market for green products. The current revised EU Ecolabel Regulation addresses this issue only as far as GPP is concerned. In fact, Article 7.4 of the EU Ecolabel Regulation calls on Member States to encourage the use of the "Manual for authorities awarding public contracts" and the setting of targets for GPP in order to foster the development of a market for EU Ecolabel products. However, the same EU Ecolabel Regulation does not contain any provision urging Member States to adopt comprehensive fiscal and regulatory relief measures in favour of EU Ecolabel Licence holders.

Author Contributions: F.I., M.B. conceived and designed the research; analyzed the data; and wrote the paper.

Conflicts of Interest: The authors declare no conflict of interest.

\section{Appendix A}

This appendix provides further bibliography non directly referred to in the main text but that, nonetheless, has contributed to the present study:

DIF > Reference 1 Bratt, C.; Hallstedt, S.; Robèrt, K.-H.; Broman, G.; Oldmark, J. Assessment of Eco-Labelling Criteria Development from a Strategic Sustainability Perspective. J. Clean. Prod. 2011, 19, 1631-1638. D'Souza, C.; Taghian, M.; Lamb, P. An empirical study on the influence of environmental labels on consumers. Corp. Commun. Int. J. 2006, 11, 162-173. Golden, J.S.; Dooley, K.J.; Anderies, J.M.; Thompson, B.H.; Gereffi, G.; Pratson, L. A Sustainable Product Indexing: Navigating the Challenge of Ecolabeling. Ecol. Soci. J. 2010, 15, 8. Gallastegui, I.G. The use of Ecolabel: A review of the literature. Eur. Environ. 2002, 12, 316-331. Horne, R.E. Limits to labels: The role of eco-labels in the assessment of product sustainability and routes to sustainable consumption. Int. J. Consum. Stud. 2009, 33, 175-182. Rex, E.; Baumann, H. Beyond Ecolabels: What Green Marketing Can Learn from Conventional Marketing. J. Clean. Prod. 2007, 15, 567-576. Banerjee, A., Solomon, B.D. Eco-labeling for energy efficiency and sustainability: A meta-evaluation of the US programs. Energy Policy 2003, 31, 109-123. Bj?rner, T.B.; Hansen, L.G.; Russell, C.S. Environmental labeling and consumers' choice-An empirical analysis of the effect of the Nordic Swan. J. Environ. Econ. Manag. 2004, 47, 411-434. Boer, J. Sustainability labelling schemes: The logic of their claims and their functions for stakeholders. Bus. Strategy Environ. 2003, 12, 254-264. Brécard, D.; Hlaimi, B.; Lucas, S.; Perraudeau, Y.; Salladarré, F. Determinants of demand for green products: An application to eco-label demand for fish in Europe. Ecol. Econ. 2009, 69, 115-125. Carmona, M. Eco-labels as signals: The role of credibility and reputation. Innov. Market. 2011, 7, 116-124. Chamorro, A.; Bañegil, T.M. Green marketing philosophy: A study of Spanish firms with Ecolabels. Corp. Soc. Responsib. Environ. Manag. 2006, 13, 11-24. Pedersen, E.R.; Neergaard, P. Caveat Emptor-Let the Buyer Beware! Environmental Labelling and the Limitations of 'Green' Consumerism. Bus. Strategy Environ. 2006, 15, 15-29. Sammer, K.; Wüstenhagen, R. 
The influence of eco-labeling on consumer behaviour results of a discrete choice analysis for washing machines. Bus. Strategy Environ. 2006, 15, 185-199. Scammon, D.L.; Mayer, R.N. Environmental Labelling and Advertising Claims: International Action and Policy Issues. In E-European Advances in Consumer Research; Association for Consumer Research: Duluth, MN, USA, 1991.

\section{References}

1. International Organization for Standardization. ISO 14024:2001-Environmental Labels and Declarations-Type I Environmental Labelling — Principles and Procedures; International Organization for Standardization: Geneva, Switzerland, 2001.

2. Testa, F.; Iraldo, F.; Vaccari, A.; Ferrari, E. Why Eco-labels can be Effective Marketing Tools: Evidence from a Study on Italian Consumers. Bus. Strategy Environ. 2013, doi:10.1002/bse.1821.

3. Horbach, J.; Rammer, C.; Rennings, K. Determinants of Eco-innovations by Type of Environmental Impact-The Role of Regulatory Push/Pull, Technology Push and Market Pull. Ecol. Econ. 2012, 78, 112-122.

4. Wagner, M. Empirical influence of environmental management on innovation: Evidence from Europe. Ecol. Econ. 2008, 66, 392-402.

5. Demirel, P.; Kesidou, E. Stimulating Different Types of Eco-Innovation in the UK: Government Policies and Firm Motivations; STPS Working Papers 1203; STPS-Science and Technology Policy Studies Center, Middle East Technical University: Ankara, Turkey, 2012.

6. Rubik, F.; Scheer, D.; Iraldo, F. Eco-labelling and product development: Potentials and experiences. Int. J. Prod. Dev. 2008, 6, doi:10.1504/IJPD.2008.020401.

7. Triguero, M.; Córcoles, C.M.C. Drivers of different types of eco-innovation in European SMEs. J. Clean. Prod. 2013, 92, 25-33.

8. Gulbrandsen, L.H. Creating markets for eco-labelling: Are consumers insignificant? Int. J. Consum. Stud. 2006, 30, 477-489.

9. Kjeldsen, U.B.; Wied, M.; Lange, P.; Tofteng, M.; Lindgaard, K. The Nordic Swan and Companies. It Is Worthwhile to Acquire the Swan Label? Nordic Council of Ministers: Copenhagen, Denmark, 2014.

10. Thidell, A. Influences, Effects and Changes from Interventions by Eco-Labelling Schemes. What a Swan Can Do? Ph.D. Thesis, IIIEE, Lund University, Lund, Sweden, 2009.

11. Lozano, J.; Blanco, E.; Rey-Maquieira, J. Can Ecolabels survive in the long run? The role of initial conditions. Ecol. Econ. 2010, 69, 2525-2534.

12. Martins Geneix, M.C. The Impact of the EU Ecolabel on Companies and the Consumer. Master's Thesis, University of Cumbria, Carlisle, UK, 2015.

13. Weiss, N.A.; Weiss, C.A. Introductory Statistics; Pearson Education: Upper Saddle River, NJ, USA, 2012.

(C) 2017 by the authors. Licensee MDPI, Basel, Switzerland. This article is an open access article distributed under the terms and conditions of the Creative Commons Attribution (CC BY) license (http:/ / creativecommons.org/licenses/by/4.0/). 